\section{Myospherulosis: An Iatrogenic Complication of Antisyphilitic Treatment?}

Colleagues - A 42-y-old Swiss male gardener was referred to the dermatology outpatient clinic in July 1988 with a history of two painful masses located symmetrically in the buttocks. The right mass had been partly excised at another institution a few weeks previously and was described as a whitish nodule. Histologic examination revealed a cystic structure filled with rounded bodies containing small spheres, compatible with coccidioidomycosis.

In view of the patient's origin, the fact that he had not traveled abroad, and his excellent physical condition, the diagnosis was reconsidered. Serology for coccidioidomycosis was negative, as were all cultures from the tissue specimen including that on Sabouraud's medium.

Further interrogation revealed a history of syphilis in 1974. The dermatology outpatient clinic files showed that at that time the patient had been treated for meningovascular syphilis with a 21-d course of intramuscular procaine penicillin.

Physical examination was unremarkable except for a firm, tender $4 \times 2-\mathrm{cm}$ nodule located deep in the left buttock. The overlying skin was unremarkable. There was no evidence of recurrence on the right buttock and the excision scar was normal. The erythrocyte sedimentation rate and leukocyte count were normal and serology for human immunodeficiency virus and venereal disease research laboratory test were negative. No abnormalities were observed on chest radiographs.

Tissue blocks were obtained from the other institution; sections were cut and stained with hematoxylin and eosin, van Gieson-Elastin, periodic acid-Schiff, Giemsa, Masson's trichrome, Pearl's stain, Grocott, and Lepehne benzioline for hemoglobin. The thick outer fibrohyalin capsule contained granulation tissue in places with occasional foreign body giant cells and groups of foam cells near cholesterol crystals in certain areas. The cavity contained a fine granular material in which were numerous thinwalled spherules of various sizes. Most of these contained 2-20 smaller spherules $(4-6 \mu \mathrm{m})$. The histologic picture and staining characteristics were consistent with myospherulosis (figure 1).

The first description, by McClatchie et al. [1] in 1969, of myospherulosis in Africa concerned cases found in subcutaneous tissue. In 1977 in the USA, Kyriakos [2] described 16 cases, all identified as ear, nose, and throat (ENT) pathology. Only 6 cases have been documented in Europe, all in France. Of the 67 cases described worldwide, 36 had an ENT localization, 28 were in peripheral soft tissues, and 3 in unusual locations: breast, ovary, and central nervous system. Only one documented case involving subcutaneous tissues has been clearly linked to an antisyphilitic treatment consisting of intramuscular injections of benzathine penicillin [3]. In the present case, the first to our knowledge to be reported from Switzerland, we think the development of myospherulosis can be directly linked to the intramuscular injections of procaine penicillin administered 14 y earlier.

Theories regarding the pathogenesis of myospherulosis have evolved from early hypotheses implicating fungi, algae, and pollens to current points of view that the lesions are iatrogenic. Experimentally it has been shown that contact between oil-based substances

Please address requests for reprints to Dr. Martine Bouvier, Unité de Santé communautaire et Médecine tropicale, Hôpital Cantonal, 1211 Genève 4, Switzerland.

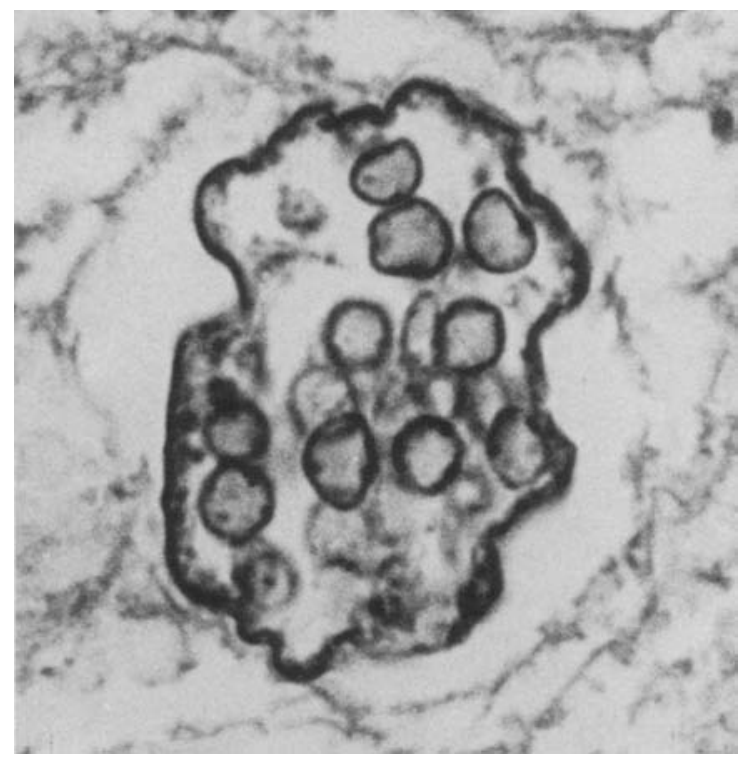

Figure 1. Sac containing numerous spherules $4-6 \mu \mathrm{m}$ in diameter (hematoxylin-eosin stain; $\times 560$ ).

and red blood cells can produce a lesion typical of myospherulosis. The substances may be exogenous, such as hemostatic gauze impregnated with petrolatum or antibiotics, as seen in the ENT cases, or oily preparations of injectable drugs as seen in the subcutaneous cases. Endogenous substances such as debris of traumatic or necrotic origin have also been implicated in the pathogenesis. The coating of erythrocytes by lipids produces the typical spherules ("bag of marbles") seen on histologic examination [4-6].

The incidence of myospherulosis is probably greatly underestimated considering the wide use of intramuscular injections, in particular of antibiotics. In the present case, the long delay before the appearance of symptoms, the unspecific character of the lesions, and the difficulty in identifying the unusual histologic lesion all delayed the correct diagnosis. This case reminds us that myospherulosis must be included in the differential diagnosis of subcutaneous nodules of undetermined origin to prevent patients from undergoing unnecessary investigations and treatment.

Sabine Kinloch, Martine Bouvier, Sebastian Lucas, N. Jeremiah CoX Dermatology and Medical Outpatient Clinics and Tropical Medicine Unit, Hopital Cantonal Universitaire, and Department of Clinical Pathology, Centre Médical Universitaire, Geneva, Switzerland; and Department of Histopathology, University College and Middlesex School of Medicine, London, UK

\section{References}

1. McClatchie S, Warambo MW, Bremner AD. Myospherulosis: a previously unreported disease? Am J Clin Pathol 1969; 51:699-704

2. Kyriakos M. Myospherulosis of the paranasal sinuses, nose 
and middle ear. A possible iatrogenic disease. Am J Clin Pathol 1977;67:118-130

3. Beurlet J, Groussard O, Ravisse P, Berger G, Destombes P. La myosphérulose: une énigme posée par de curieux "sacs de billes." Arch Anat Cytol Pathol 1979;27:5-13

4. Rosai $J$. The nature of myospherulosis of the upper respiratory tract. Am J Clin Pathol 1978;69:475-481
5. Wheeler TM, McGavran MH. Myospherulosis - further observations. Am J Clin Pathol 1980;73:685-686.

6. Vuong PN, Baviera E, Houissa-Vuong S, Fombeur JP, Oriol $R$, Mesnil $C$. La myosphérulose: une maladie iatrogène. A propos de deux observations avec étude immunomorphologique et expérimentale. Semin Hop Paris 1985;61:9-15

THE JOURNAL OF INFECTIOUS DISEASES - VOL. 160, NO. 5 - NOVEMBER 1989

(C) 1989 by The University of Chicago. All rights reserved. 0022-1899/89/6005-0038\$01.00

\section{Registry on Mucormycosis in Dialysis Patients}

Colleagues - Sane et al. [1] reported a patient with myelofibrosis and transfusional iron overload, treated with deferoxamine, who died from disseminated mucormycosis caused by Rhizopus oryzae. An analogous case was reported recently [2], and deferoxamine therapy is proposed to be the risk factor for this zygomycete infection.

Sane et al. [1] noted that mucormycosis has been reported in hemodialysis patients worldwide. As of 1 February 1989, 25 cases had been reported among nondiabetic dialysis patients [3-9], and we are aware of several more unpublished cases.

Several authors have linked this infectious complication to the use of deferoxamine. Of the 25 reported dialysis patients, 22 were receiving deferoxamine for the treatment of either aluminum overload ( 18 cases) or iron overload ( 4 cases). The infection was fatal in $22(88 \%)$ of 25 patients. In most instances, the diagnosis was made postmortem. When the fungus was cultured, it was always genus Rhizopus. The mechanism underlying this fulminant infection in dialysis patients treated with deferoxamine is unknown.

To identify predisposing factors, we are establishing a registry of dialysis patients who have developed mucormycosis. Thus, we request physicians who have observed this mycosis in dialysis patients to contact us. We will respond with a detailed questionnaire in the hope of identifying risk factors for this infection. (To respond, see footnotes.)

To report patients to the registry, questionnaires may be obtained from the following: Dr. Johan Boelaert, Algemeen Ziekenhuis St Jan, B-8000 Brugge, Belgium; Dr. Andrew Fenves, Baylor University Medical Center, 3550 Gaston Ave., Dallas, TX 75246; and Dr. Jack Coburn, Nephrology Section (W111L), West Los Angeles V.A. Medical Center, Los Angeles, CA 90073.

Reprints are available from Dr. Boelaert at the address shown above.
Johan R. Boelaert, Andrew Z. Fenves, Jack W. Coburn Algemeen Ziekenhuis St Jan, Brugge, Belgium; Baylor University Medical Center, Houston, Texas; West Los Angeles (California) Veterans Administration Hospital

\section{References}

1. Sane A, Manzi S, Perfect J, Herzberg AJ, Moore JO. Deferoxamine treatment as a risk factor for zygomycete infection [letter]. J Infect Dis 1989;159:151-152

2. Rex JH, Ginsberg AM, Fries LF, Pass HI, Kwong-Chung KJ. Cunninghamella bertholletiae infection associated with deferoxamine therapy. Rev Infect Dis 1988;10:1187-1194

3. Boelaert JR, van Roost GF, Vergauwe PL, Verbanck JJ, de Vroey $\mathrm{C}$, Segaert MF. The role of desferrioxamine in dialysisassociated mucormycosis: report of three cases and review of the literature. Clin Nephrol 1988;29:261-266

4. Windus DW, Stokes TJ, Julian BA, Fenves AZ. Fatal rhizopus infections in hemodialysis patients receiving deferoxamine. Ann Intern Med 1987;107:678-680

5. Segal R, Zoller KA, Sherrard DJ, Coburn JW. Mucormycosis: a life-threatening complication of deferoxamine therapy in long-term dialysis patients [abstract]. Kidney Int 1988; 33:238

6. Sombolos K, Kalekou H, Barboutis K, Tzarou V. Fatal phycomycosis in a hemodialyzed patient receiving deferoxamine [letter]. Nephron 1988;49:169-170

7. Kerr PG, Turner H, Davidson A, Bennett C, Maslen M. Zygomycosis requiring amputation of the hand: an isolated case in a patient receiving haemodialysis. Med J Aust 1988;148:258-259

8. Morris DJ, Altus P. Rhinocerebral mucormycosis in an anephric patient. South Med J 1988;81:400-403

9. Hisanaga $S$, Fujimoto $S$, Wakisaka $O$, Yamamoto $Y$, Tamaka $\mathrm{K}$, Koita H, Kono T. Cardiac mucormycosis associated with deferoxamine use in a hemodialysis patient [in Japanese]. Kidney and Dialysis 1988;24:143-148 